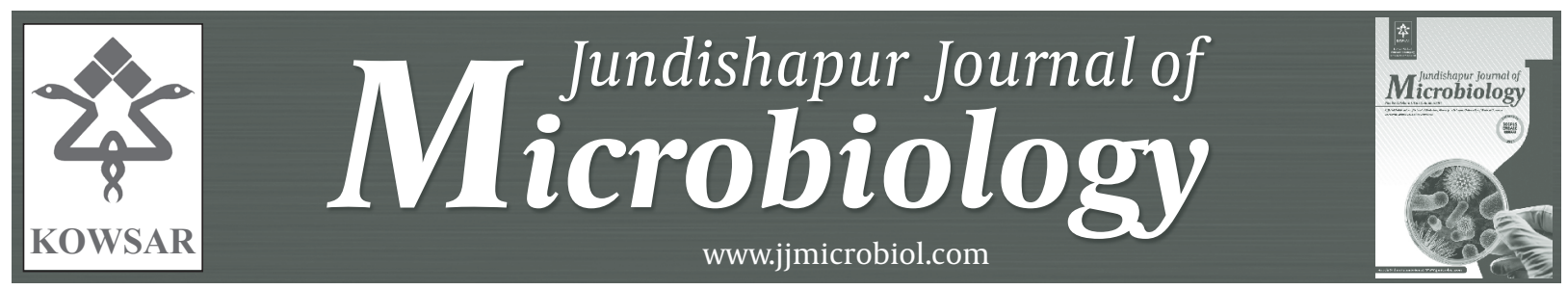

\title{
Helicobacter pylori Infection: Regulatory T Cells and Their Participation in the Immune Response
}

\author{
Tania Beatriz Romero-Adriàn ${ }^{1, *}$, Jorymar Leal-Montiel ${ }^{2}$ \\ ${ }^{1}$ Faculty of Medicine, University of Zulia, Maracaibo, Venezuela \\ ${ }^{2}$ Institute of Biological Research, Faculty of Medicine, University of Zulia, Maracaibo, Venezuela \\ ${ }^{*}$ Corresponding author: Tania Beatriz Romero-Adriàn, 69 B, Avenue 77, 49th Street, Panamericano Sector, Maracaibo, Venezuela. Tel: +26-17532659, E-mail: \\ betrizromero@cantv.net.
}

\begin{abstract}
A B S T R A C T
Helicobacter pylori (H. pylori) is a Gram-negative bacterium that colonizes the human stomach and affects more than half of the global human population. This microorganism shows variations in its geographical distribution and causes chronic gastritis, peptic ulcer, gastric adenocarcinoma and mucosa-associated lymphoid tissue lymphoma. The development of these clinical entities depends on the bacterial strain and its virulence, the host genetic predisposition, immunological response, concurrent infections and infestations.

In the immune response for the eradication of $H$. pylori different types of cells and mediators are involved. Studies reveal that the bacterial infection predominate the cytokines of Th1 phenotype with secretion of abundant levels of IFN-gamma and IL-2 by mucosal T cells. The inability of patients to clear $\mathrm{H}$. pylori infections is a consequence of active immunosuppression and evasive mechanisms of bacteria. Many immune factors are involved: chronic exposure of the DCs to H. pylori leading to DC exhaustion, influence of regulatory T(Treg) cells through immunosuppressive cytokines, and the mast cells that change the gastric mucosal environments among others.

In the current review, the focus is restricted to Tregs and their participation in the anti-bacterial response. These cells are a heterogeneous T-cell subpopulation with biological actions determinants in the pathogenesis of $H$. pylori infection. Studies have demonstrated that the activation of Treg cells cause down-regulation of adaptive immunity facilitating the persistence of infection by H.pylori. Even, the regulations of the Th17/ Treg and Th1/Treg balances are important in the immune response against the pathogen, in the persistent colonization of the bacterium and in the affectation of the gastrointestinal system.
\end{abstract}

Keywords: Helicobacter pylori; Regulatory T cells; Cytokines

Copyright ( 2013, Ahvaz Jundishapur University of Medical Sciences; Published by Kowsar Corp.

Article type: Review Article; Received: 03 May 2012; Revised: 17 Jul 2012; Accepted: 08 Aug 2012; Epub: 01 Jun 2013 ; Ppub: Jun 2013

-Implication for health policy/practice/research/medical education:

Studies of Regulatory T cells in Helicobacter pylori infection can stimulate further research to search new treatments that affect the immune system and control the bacterial infection. Factors that contribute to the failure of the immune response to clear the bacterial organism have not been fully elucidated. The generation of a marked Treg has recently been postulated as key factor in this failure. The implementation of health policies and the disclosure of knowledge are the result of new research contributions

P Please cite this paper as:

Romero-Adriàn T, Leal-Montiel J. Helicobacter pylori Infection: Regulatory T Cells and Their Participation in the Immune Response. Jundishapur J Microbiol. 2013;6(4):e5183. DOI: 10.5812/jjm.5183.

Copyright (C) 2013, Ahvaz Jundishapur University of Medical Sciences; Published by Kowsar Corp.

This is an Open Access article distributed under the terms of the Creative Commons Attribution License (http://creativecommons.org/licenses/by/3.0), which permits unrestricted use, distribution, and reproduction in any medium, provided the original work is properly cited. 


\section{Introduction}

Helicobacter pylori is a motile Gram-negative spiral bacterium that colonizes the human gastric epithelium. It was first reported to be successfully cultured from patient biopsies under micro-aerophilic conditions in 1984 (1). Infection is believed to occur predominantly in early childhood, and it persists for life unless successfully treated with antimicrobial therapy. In developing countries more than $80 \%$ of the adult population can be infected (2). In Waro communities of Venezuela, the seroprevalence of the infection was $38 \%$ in children and $84 \%$ in their mothers $(3,4)$. H. pylori has been classified by the WHO as a Group I carcinogen (5).

H. pylori outer membrane proteins, including BabA, SabA, AlpA, AlpB, and HopZ, can mediate H. pylori adherence to gastric epithelial cells for the activation of numerous signaling pathways (6) and permits efficient delivery of toxins or other effector molecules into the cells. Studies in an animal model indicate that attachment of H. pylori to epithelial cells is involved in gastric mucosal inflammation, production of autoantibodies, and parietal cell loss (7). Several H. pylori factors are known to interact directly with immune cells and modulate immune responses to $\mathrm{H}$. pylori. For example, VacA alters the function of T lymphocytes, B cells, macrophages, and mast cells (8-11) and HP-NAP acts on neutrophils, mast cells, and monocytes $(12,13)$

For many years, studies have been conducted involving the subset of T cells and cytokines in different physiological and pathological clinical entities (14-22). In H. pylori infection all investigations indicate the predominance of the Th1 response $(14,21,23)$. However, other cellular phenotypes such as Th2, Th17 and Treg that secrete inmunomodulate cytokines may participate (21). In the setting of $H$. pylori infection, multiple cytokines in the gastric mucosa (including TNF, IFN- $\gamma$, IL-1 $\beta$, IL-6, IL-8, and IL-18) are predicted to have proinflammatory effects, whereas IL-10 and TGF- $\beta$ are cytokines that may limit the inflammatory response (21). Early studies suggest that IL-2 is specifically required for the development and maintenance of nTregs (24). Research shows that interactions among epithelial cells, DC and T cells bridged by cytokines are important for the generation of thymic nTregs (25). Preserved functionality of Treg cells can facilitate the immune response against infectious agents due to their regulatory effects on other subpopulations of $\mathrm{T}$ lymphocytes and recruitment of cells at the site of infection (26).

\section{Regulatory Tcells:GeneralCharacteristics}

With the development of new technologies in the $1990 \mathrm{~s}$ convincing evidences are presented in relation to the existence of immunosuppressive cells called Regulatory $\mathrm{T}$ cells (27).

There are different subsets of Treg cells. CD4+CD25 high
Treg cells are the best-described subset. A key characteristic of CD4+CD25 high Treg cells is its ability to induce anergy in vitro and suppress immune responses $(28,29)$. Some studies suggest that CD4+CD25 high Treg cells inhibit proliferation of effector CD4+CD25-T cells and CD8+ T cells by arresting the proliferation of these cells at G1-S interphase of the cell cycle (30). Recent data also indicate that $\mathrm{CD} 4+\mathrm{CD} 25$ high Treg cells regulate through their cytokines to Th17 cells (31). The total number of CD4+CD25 high Treg cells in human peripheral blood increases with age, despite thymic involution (32). Surface markers associated with CD4+CD25high Treg cells are of identification, homing/trafficking, activation/cell death and suppressive function. These cells have been classified into into natural ( $\mathrm{n}$ ) and inducible (i). The first originated in the thymus and the second coming of naive T cells. Natural Treg cells represent 5-10\% of CD4+CD8- thymocytes in humans, mice, and rats (33).

CD4+CD25high Treg cells participate in immune responses against malignant cells $(34,35)$ allogeneic organs, stem-cell grafts (36) and infectious agents (37). Although CD4+CD25 high Treg cells regulate both Th1 and Th2 immune responses, Th2 cells may partially escape this suppressive activity by regulating protein, such as IL-4, IL-7, and IL- contrast, the proliferation of Th1 cells is only restored by the administration of IL-15 (38). Under appropriate conditions, CD4+CD25 high Treg cells are able to confer suppressive capacity on CD4+CD25- T cells, converting them to either Th3 or Tr1 cells $(39,40)$. Also, Treg cells possess properties of plasticity and interconvertibility under certain circumstances. These cells are transformed into others phenotypes such as Th1, Th2 and $\operatorname{Th} 17(41,42)$.

\section{Role of Regulatory $T$ cells in the Helicobacter pylori Infection}

Investigations have implicated Treg cells in the pathogenesis of the Helicobacter pylori infection. Treg cells suppress excessive activation of CD4+ as well as CD8+ to control gastric inflammation and persistent colonization of the bacterium $(43,44)$.

Studies show that $H$. pylori-infected individuals have increased frequencies of CD4+CD25 high $\mathrm{T}$ cells in both the stomach and duodenal mucosa compared to uninfected controls. These cells express FOXP3, a key gene for the development and function of Treg cells, as well as high levels of the cytotoxic T lymphocyte-associated antigen 4 (CTLA4) proteins. Mucosal CD4+CD25 high $\mathrm{T}$ cells are present in individuals with asymptomatic $H$. pylori infections as well as in duodenal ulcer patients. The frequencies of CD4+CD25 high cells are also increased in the stomachs of $H$. pylori-infected patients with gastric adenocarcinoma (45). These findings suggest that regulatory T cells may suppress mucosal immune responses and thereby contribute to the persistence of $H$. pylori infections (46). 
A recent study has demonstrated the elevation and positive correlation of Tregs with histological grade of chronic gastritis, atrophic gastritis and adenocarcinoma, and its decrease and negative correlation with histological grade of intestinal metaplasia. However, the relationship between CD4+CD25+ Tregs and precancerous lesions of the stomach remain unclear (47).

Researchers have shown that the decrease of the gastric inflammation in infected children is associated with a marked increment in the number of Treg cells and the levels of their cytokines such as IL-10 and TGF-beta. IL10-producing $\mathrm{T}$ lymphocytes are important in the control of inflammation induced by $H$. pylori and facilitate persistence of the bacterium on the gastric mucosa. This is not observed in mice with IL-10 "knockout" $(48,49)$. Investigations have shown shown that TGF- $\beta$ acts inhibited the secretion of pro-inflammatory cytokines: Th1 and Th17. "Knockout" mice for TGF- $\beta$ develop a deadly generalized inflammation (50). Study has demonstrated that the naïve CD4+ T cell development into Treg was enhanced in the presence of GECs (Gastric Epithelial Cells) derived TGF- $\beta$. This cytokine may be among the key factors which direct the T cell response during $H$. pylori infection (51). Treg cells regulate and maintain the tissue injury and overwhelming infection in balance. Excessive Treg activity is observed in persistent infections such leishmaniasis, malaria, tuberculosis (52-54), H. pylori infection, Human Immunodeficiency Virus (HIV) and Hepatitis C Virus (HCV) infections $(46,55-57)$, suggesting the possibility of a link between pathogen persistence and Treg mediated suppression.

Studies have revealed that $H$. pylori-infected patients express increased levels of FOXP3 mRNA and protein in gastric lymphocytes. The induction of the Treg response contributes to equilibrium between the host and the bacterium not only the survival of $H$. pylori but also the prevention of the destructive inflammation (58). Other studies agree with these results and show an inverse relationship between the risk of peptic ulcer disease and the frequency of regulatory T cells. Even, indicate that the reduction of Treg increases bacterial colonization (45). The induction of Tregs by H. pylori may prove to be a major adaptation to evade host immunity. The bacterium is able to stimulate DCs to prime Tregs and the functional significance of $H$. pylori-induced Treg response is the restriction of Th17 priming. Inhibition of Th17 immunity may allow chronic persistence of the bacteria (59), Researchers (45) indicate that the potent Treg response may affect the development of vaccine against $H$. pylori.

Studies show that Tregs did not increase in peripheral blood in H. pylori-infected patients, but the activation of humoral immunity and Th2 polarization was appreciated. These changes may induce systemic autoimmune diseases (60).

It can be hypothesized that the regulations of the Th17|
Treg and Th1/Treg balances are important in the response immune in the H. pylori infection. The The Tregs cells exert their immunosuppressive effects on other cellular phenotypes (Th1, Th2 and Th17) based on the functional activity and secretion of cytokines. Therefore, to understand the development of Tregs during infection with $H$. pylori it it is crucial to interpret not only the immunopathogenic mechanisms involved but also multiple outcomes of the infection. Certainly, the $H$. pylori infection is a multi-factorial pathology and each of the host (genetic and nutritional state) and bacterium (virulent strains and multiple strains) dependent factors have their influences on the immune system. Also, a concomitant helminthic infection that triggers Th2 phenotype may affect the Th1 cell responses associated with $H$. pylori infection and limit the pathological consequences of $H$. pylori gastric colonization; in particular, gastric atrophy $(21,61)$.

The identification of regulatory $\mathrm{T}$ cells and their cytokines at the site of $H$. pylori infection in humans may also have important implications to understand to understand immune responses to other infections.

\section{Conclusions}

Many cells and mediators are involved in the pathogenesis of $H$. pylori infection. Inflammation of the gastric mucosa is dependent on T lymphocytes. Studies have shown that mice deficient in $\mathrm{T}$ cells and infected by the bacteria do not develop gastritis. It is considered that specific regulatory T cells that suppress memory $\mathrm{T}$ cells could contribute to the persistence of the pathogen. Studies have demonstrated that Tregs have different regulatory mechanisms at their disposal. They can be divided into four basic modes of action such as inhibitory cytokines, cytolysis, metabolic disruption and modulation of APC function. The consequences of Treg mediated suppression of the immune response during infection are controversial. Studies show that while Treg cells, limit local tissue damage and prevent sterilizing immunity against the pathogen, allow the persistent of infection.

This results in protective immunity against a subsequent bacterial challenge. While this 'symbiotic relationship' may be beneficial to the host, there is also evidence to suggest that Tregs can be detrimental to the host. The regulations of the Th17/Treg and Th1/Treg balances may influence intestinal immunity and tolerance, dictating the outcome of luminal bacterial infection. More knowledge about the molecular mechanisms driving Treg cell proliferation, activation, and survival is required.

\section{Acknowledgements}

We are grateful to research staff at the Institute of Biological Research Faculty of Medicine University of Zulia, Maracaibo, Venezuela for its constructive advice in the preparation of the manuscript. 


\section{Financial Disclosure}

This work was funded by the Institute of Biological Research Faculty of Medicine University of Zulia, Maracaibo, Venezuela.

\section{Funding Support}

None Declared.

\section{Authors' Contribution}

None declared.

\section{References}

1. Marshall BJ, Warren JR. Unidentified curved bacilli in the stomach of patients with gastritis and peptic ulceration. Lancet 1984:1(8390):1311-5.

2. Suerbaum S, Michetti P. Helicobacter pylori infection. $\mathrm{N}$ Engl J Med. 2002;347(15):1175-86.

3. Ortiz D, Cavazza ME, Rodriguez O, Hagel I, Correnti M, Convit J. Prevalence of Helicobacter pylori infection in Warao lineage communities of Delta Amacuro State, Venezuela. Mem Inst Oswaldo Cruz. 2003;98(6):721-5.

4. Torres J, Perez-Perez G, Goodman KJ, Atherton JC, Gold BD, Harris PR, et al. A comprehensive review of the natural history of Helicobacter pylori infection in children. Arch Med Res. 2000;31(5):43169.

5. IARC Working Group on the Evaluation of Carcinogenic Risks to Humans. Schistosomes, liver flukes and Helicobacter pylori. 1994.

6. Guillemin K, Salama NR, Tompkins LS, Falkow S. Cag pathogenicity island-specific responses of gastric epithelial cells to Helicobacter pylori infection. Proc Natl Acad Sci U S A. 2002;99(23):1513641.

7. Guruge IL, Falk PG, Lorenz RG, Dans M, Wirth HP, Blaser MJ, et al. Epithelial attachment alters the outcome of Helicobacter pylor infection. Proc Natl Acad Sci U S A. 1998;95(7):3925-30.

8. Gebert B, Fischer W, Weiss E, Hoffmann R, Haas R. Helicobacter pylori vacuolating cytotoxin inhibits T lymphocyte activation. Science. 2003;301(5636):1099-102.

9. Sundrud MS, Torres VJ, Unutmaz D, Cover TL. Inhibition of primary human T cell proliferation by Helicobacter pylori vacuolating toxin (VacA) is independent of VacA effects on IL-2 secretion. Proc Natl Acad Sci U S A. 2004;101(20):7727-32.

10. Supajatura V, Ushio H, Wada A, Yahiro K, Okumura K, Ogawa H, et al. Cutting edge: VacA, a vacuolating cytotoxin of Helicobacter pylori, directly activates mast cells for migration and production of proinflammatory cytokines. J Immunol. 2002;168(6):2603-7.

11. Zheng PY, Jones NL. Helicobacter pylori strains expressing the vacuolating cytotoxin interrupt phagosome maturation in macrophages by recruiting and retaining TACO (coronin 1) protein. Cell Microbiol. 2003;5(1):25-40.

12. Montemurro P, Barbuti G, Dundon WG, Del Giudice G, Rappuoli $\mathrm{R}$, Colucci M, et al. Helicobacter pylori neutrophil-activating protein stimulates tissue factor and plasminogen activator inhibitor-2 production by human blood mononuclear cells.J Infect Dis. 2001;183(7):1055-62.

13. Montemurro P, Nishioka H, Dundon WG, de Bernard M, Del Giudice G, Rappuoli R, et al. The neutrophil-activating protein (HPNAP) of Helicobacter pylori is a potent stimulant of mast cells. EurJ Immunol. 2002;32(3):671-6.

14. Bamford KB, Fan X, Crowe SE, Leary JF, Gourley WK, Luthra GK, et al. Lymphocytes in the human gastric mucosa during Helicobacter pylori have a T helper cell 1 phenotype. Gastroenterology. 1998;114(3):482-92.

15. Leal JY, Castejon HV, Romero T, Ortega P, Gomez G, Amaya D, et al. [Serum values of cytokines in children with vitamin A deficiency disorders]. Invest Clin. 2004;45(3):243-56.

16. Leal JY, Castejon HV, Romero T, Ortega P, Gomez G, Amaya D, et al. [Serum levels of interferon-gamma and interleukine-10 in anemic children with vitamin A deficiency]. Arch Latinoam Nutr. 2006;56(4):329-34

17. Leal JY, Romero T, Ortega P, Amaya D. [Serum values of interleukin-10, gamma-interferon and vitamin A in female adolescents] Invest Clin. 2007;48(3):317-26.

18. Monsalve F, Romero AT, Estevez J, Costa L, Callejas D. [Serum levels of soluble CD30 molecule in hepatitis B virus infection]. Rev Med Chil. 2001;129(11):1248-52.

19. Monsalve-De Castillo F, Romero TA, Estevez J, Costa LL, Atencio R, Porto L, et al. Concentrations of cytokines, soluble interleukin-2 receptor, and soluble $\mathrm{CD} 30$ in sera of patients with hepatitis B virus infection during acute and convalescent phases. Clin Diagn Lab Immunol. 2002;9(6):1372-5.

20. Romero-Adrian T, Ruiz A, Molina-Vilchez R, Estevez J, Atencio R. Interleukin-2 receptor serum concentrations in normal pregnancy and pre-eclampsia. Invest Clin. 2002;43(2):73-8.

21. Romero-Adrian TB, Leal-Montiel J, Monsalve-Castillo F, MengualMoreno E, McGregor EG, Perini L, et al. Helicobacter pylori: bacterial factors and the role of cytokines in the immune response. Curr Microbiol. 2010;60(2):143-55.

22. Shokouhi Shoormasti R, Azimdoost A, Saghafi S, Movahhedi M, Haghi Ashtiani MT, Pourpak Z, et al. Normal range determination of lymphocytes subsets in normal adults in Iran. Iran J Allergy Asthma Immunol. 2011;10(4):295-8.

23. Sommer F, Faller G, Konturek P, Kirchner T, Hahn EG, Zeus J, et al. Antrum- and corpus mucosa-infiltrating CD4(+) lymphocytes in Helicobacter pylori gastritis display a Th1 phenotype. Infect Immun. 1998;66(11):5543-6.

24. Setoguchi R, Hori S, Takahashi T, Sakaguchi S. Homeostatic maintenance of natural Foxp3(+) CD25(+) CD4(+) regulatory T cells by interleukin (IL)-2 and induction of autoimmune disease by IL-2 neutralization.J Exp Med. 2005;201(5):723-35.

25. Watanabe N, Wang YH, Lee HK, Ito T, Cao W, Liu YJ. Hassall's corpuscles instruct dendritic cells to induce $\mathrm{CD} 4+\mathrm{CD} 25+$ regulatory T cells in human thymus. Nature. 2005;436(7054):1181-5.

26. Belkaid Y. Role of Foxp3-positive regulatory T cells during infection. Eur Immunol. 2008;38(4):918-21.

27. Sakaguchi S, Sakaguchi N, Asano M, Itoh M, Toda M. Immunologic self-tolerance maintained by activated T cells expressing IL-2 receptor alpha-chains (CD25). Breakdown of a single mechanism of self-tolerance causes various autoimmune diseases. J Immunol. 1995;155(3):1151-64

28. Adalid-Peralta L, Fragoso G, Fleury A, Sciutto E. Mechanisms underlying the induction of regulatory $\mathrm{T}$ cells and its relevance in the adaptive immune response in parasitic infections. Int J Bio Sci. 2011;7(9):1412-26.

29. Jonuleit H, Schmitt E, Kakirman H, Stassen M, Knop J, Enk AH. Infectious tolerance: human CD25(+) regulatory T cells convey suppressor activity to conventional CD4(+) T helper cells. J Exp Med. 2002;196(2):255-60.

30. de la Rosa M, Rutz S, Dorninger H, Scheffold A. Interleukin-2 is essential for $\mathrm{CD} 4+\mathrm{CD} 25+$ regulatory $\mathrm{T}$ cell function. Eur J Immunol. 2004:34(9):2480-8.

31. Veldhoen M, Hocking RJ, Atkins CJ, Locksley RM, Stockinger B. TGFbeta in the context of an inflammatory cytokine milieu supports de novo differentiation of IL-17-producing T cells. Immunity. 2006;24(2):179-89.

32. Gregg R, Smith CM, Clark FJ, Dunnion D, Khan N, Chakraverty $\mathrm{R}$, et al. The number of human peripheral blood CD4+ CD25high regulatory T cells increases with age. Clin Exp Immunol. 2005;140(3):540-6.

33. Milojevic D, Nguyen KD, Wara D, Mellins ED. Regulatory T cells and their role in rheumatic diseases: a potential target for nove therapeutic development. Pediatr Rheumatol Online J. 2008;6:20.

34. Johnson BD, Jing W, Orentas RJ. CD25+ regulatory T cell inhibition enhances vaccine-induced immunity to neuroblastoma. J Immunother. 2007;30(2):203-14.

35. Stassen M, Fondel S, Bopp T, Richter C, Muller C, Kubach J, et al. Human CD25+ regulatory T cells: two subsets defined by the integrins alpha 4 beta 7 or alpha 4 beta 1 confer distinct suppressive properties upon CD4+ T helper cells. Eur J Immunol. 
2004;34(5):1303-11.

36. Xia G, He J, Zhang Z, Leventhal JR. Targeting acute allograft rejection by immunotherapy with ex vivo-expanded natural CD4+ CD25+ regulatory T cells. Transplantation. 2006;82(12):1749-55.

37. Raghavan S, Suri-Payer E, Holmgren J. Antigen-specific in vitro suppression of murine Helicobacter pylori-reactive immunopathological T cells by CD4CD25 regulatory T cells. Scand J Immunol. 2004;60(1-2):82-8.

38. Cosmi L, Liotta F, Angeli R, Mazzinghi B, Santarlasci V, Manetti R, et al. Th2 cells are less susceptible than Th1 cells to the suppressive activity of $\mathrm{CD} 25+$ regulatory thymocytes because of their responsiveness to different cytokines. Blood. 2004;103(8):3117-21.

39. Dieckmann D, Bruett CH, Ploettner H, Lutz MB, Schuler G. Human $\mathrm{CD} 4(+) \mathrm{CD} 25(+)$ regulatory, contact-dependent $\mathrm{T}$ cells induce interleukin 10-producing, contact-independent type 1-like regulatory T cells [corrected]. J Exp Med. 2002;196(2):247-53.

40. Dieckmann D, Plottner H, Berchtold S, Berger T, Schuler G. Ex vivo isolation and characterization of $\mathrm{CD} 4(+) \mathrm{CD} 25(+) \mathrm{T}$ cells with regulatory properties from human blood. I Exp Med. 2001;193(11):1303-10.

41. Wan YY, Flavell RA. Regulatory T-cell functions are subverted and converted owing to attenuated Foxp3 expression. Nature. 2007;445(7129):766-70.

42. Williams LM, Rudensky AY. Maintenance of the Foxp3-dependent developmental program in mature regulatory $\mathrm{T}$ cells requires continued expression of Foxp3. Nat Immunol. 2007;8(3):277-84.

43. Ernst PB, Gold BD. The disease spectrum of Helicobacter pylori: the immunopathogenesis of gastroduodenal ulcer and gastric cancer. Annu Rev Microbiol. 2000;54:615-40.

44. Meyer F, Wilson KT, James SP. Modulation of innate cytokine responses by products of Helicobacter pylori. Infect Immun. 2000;68(11):6265-72.

45. Raghavan S, Quiding-Jarbrink M. Immune modulation by regulatory T cells in Helicobacter pylori-associated diseases. Endocr Metab Immune Disord Drug Targets. 2012;12(1):71-85.

46. Lundgren A, Stromberg E, Sjoling A, Lindholm C, Enarsson K, Edebo A, et al. Mucosal FOXP3-expressing CD4+CD25high regulatory T cells in Helicobacter pylori-infected patients. Infect Immun. 2005;73(1):523-31.

47. Cheng HH, Tseng GY, Yang HB, Wang HJ, Lin HJ, Wang WC. Increased numbers of Foxp3-positive regulatory $\mathrm{T}$ cells in gastritis, peptic ulcer and gastric adenocarcinoma. World J Gastroenterol. 2012;18(1):34-43.

48. Ismail HF, Fick P, Zhang J, Lynch RG, Berg DJ. Depletion of neutrophils in IL-10(-/-) mice delays clearance of gastric Helicobacter infection and decreases the Th1 immune response to Helicobacter. JImmunol. 2003;170(7):3782-9.

49. Oderda G, Vivenza D, Rapa A, Boldorini R, Bonsignori I, Bona G. Increased interleukin-10 in Helicobacter pylori infection could be involved in the mechanism protecting from allergy. J Pediatr Gastroenterol Nutr. 2007;45(3):301-5.
50. Eisenberg JC, Czinn SJ, Garhart CA, Redline RW, Bartholomae WC Gottwein JM, et al. Protective efficacy of anti-Helicobacter pylori immunity following systemic immunization of neonatal mice. Infect Immun. 2003;71(4):1820-7.

51. Beswick EJ, Pinchuk IV, Earley RB, Schmitt DA, Reyes VE. Role of gastric epithelial cell-derived transforming growth factor beta in reduced CD4+ T cell proliferation and development of regulatory T cells during Helicobacter pylori infection. Infect Immun. 2011;79(7):2737-45

52. Belkaid Y, Piccirillo CA, Mendez S, Shevach EM, Sacks DL. CD4+CD25+ regulatory T cells control Leishmania major persistence and immunity. Nature. 2002;420(6915):502-7.

53. Hisaeda H, Maekawa Y, Iwakawa D, Okada H, Himeno K, Kishihara $\mathrm{K}$, et al. Escape of malaria parasites from host immunity requires CD4+ CD25+ regulatory T cells. Nat Med. 2004;10(1):29-30.

54. Scott-Browne JP, Shafiani S, Tucker-Heard G, Ishida-Tsubota K, Fontenot JD, Rudensky AY, et al. Expansion and function of Foxp3-expressing T regulatory cells during tuberculosis. J Exp Med. 2007;204(9):2159-69.

55. Andersson J, Boasso A, Nilsson J, Zhang R, Shire NJ, Lindback S, et al. The prevalence of regulatory $\mathrm{T}$ cells in lymphoid tissue is correlated with viral load in HIV-infected patients. J Immunol. 2005;174(6):3143-7.

56. Kinter AL, Hennessey M, Bell A, Kern S, Lin Y, Daucher M, et al $\mathrm{CD} 25(+) \mathrm{CD} 4(+)$ regulatory T cells from the peripheral blood of asymptomatic HIV-infected individuals regulate $\mathrm{CD} 4(+)$ and CD8(+) HIV-specific T cell immune responses in vitro and are associated with favorable clinical markers of disease status. J Exp Med. 2004;200(3):331-43.

57. Pereira LE, Villinger F, Onlamoon N, Bryan P, Cardona A, Pattanapanysat K, et al. Simian immunodeficiency virus (SIV) infection influences the level and function of regulatory T cells in SIV-infected rhesus macaques but not SIV-infected sooty mangabeys. $J$ Virol. 2007;81(9):4445-56.

58. Rad R, Brenner L, Bauer S, Schwendy S, Layland L, da Costa CP, et al. CD25+/Foxp3+ T cells regulate gastric inflammation and Helicobacter pylori colonization in vivo. Gastroenterology. 2006;131(2):525-37.

59. Kao JY, Zhang M, Miller MJ, Mills JC, Wang B, Liu M, et al. Helicobacter pylori immune escape is mediated by dendritic cell-induced Treg skewing and Th17 suppression in mice. Gastroenterology. 2010;138(3):1046-54.

60. Satoh Y, Ogawara H, Kawamura O, Kusano M, Murakami H. Clinical Significance of Peripheral Blood T Lymphocyte Subsets in Helicobacter pylori-Infected Patients. Gastroenterol Res Pract. 2012;2012:819842.

61. Fox JG, Beck P, Dangler CA, Whary MT, Wang TC, Shi HN, et al Concurrent enteric helminth infection modulates inflammation and gastric immune responses and reduces helicobacterinduced gastric atrophy. Nat Med. 2000;6(5):536-42. 